Leadership and the Humanities, Vol. 3 No. 2, 2015, pp. 158-161

\title{
Interview
}

\section{Talking leadership with Camille Paglia}

\author{
Interview conducted by Michael Harvey via email, October 2014
}

Camille Paglia is the University Professor of Humanities and Media Studies at the University of the Arts in Philadelphia, where she has taught since 1984. She received her BA from the State University of New York at Binghamton in 1968 and her MPhil and $\mathrm{PhD}$ degrees from Yale University in 1971 and 1974 respectively.

Her six books are: Sexual Personae: Art and Decadence from Nefertiti to Emily Dickinson (1990); Sex, Art, and American Culture (1992); Vamps \& Tramps: New Essays (1994); The Birds, a study of Alfred Hitchcock published in 1998 by the British Film Institute in its Film Classics Series; Break, Blow, Burn: Camille Paglia Reads Forty-Three of the World's Best Poems (2005), and Glittering Images: A Journey through Art from Egypt to Star Wars (2012). Her third essay collection is under contract to Pantheon Books.

Professor Paglia was a co-founding contributor and columnist for Salon.com, from its debut issue in 1995. She has written numerous articles on art, literature, popular culture, feminism, politics, and religion for publications around the world. Her essay, 'Theater of Gender: David Bowie at the Climax of the Sexual Revolution,' was commissioned by the Victoria \& Albert Museum for the catalog of its major exhibit of Bowie costumes, which opened in London in 2013 and is currently touring internationally.

Harvey: In the west, classical and traditional models and exemplars of leadership are almost exclusively male. To what extent do these traditions still matter to the exploration of, and education about, leadership - or to what extent ought they to be discarded, or filtered, or otherwise 'corrected'?

Paglia: Male leadership is certainly not a Western convention but a worldwide phenomenon that feminism has never adequately analysed or explained. Except for a few strong-willed queens who ruled in the absence of a crown prince, political governance and commercial management were masculine prerogatives from the dawn of civilization. The situation has changed only because of the relatively recent shift from an agrarian to an industrial and now service-sector economy, where women can perform the same office-bound tasks as men. Women continue to make inroads into many fields, such as engineering, once dominated by men, and their presence in such leadership positions as mayor, governor, cabinet head, and university president or dean has become commonplace. However, in virtually all cases, women are entering organizational systems created by men and still permeated by male assumptions and values.

The reason for this ancient disparity was not, as vengefully alleged by too many feminists, an oppressive patriarchy motivated by misogyny but rather the natural 
division of labor that ceded to women complete control over the complex operations of pregnancy, childbirth, and infant and child care. Women remained at the hearth because it was preferable for their own central goals to do so. In the agrarian era, there was the world of men and the world of women, with very little crossover. We are still sorting through the innumerable thorny problems that have arisen from women correctly demanding admission (on modern civil rights grounds) to the world of men and then voicing surprise and dissatisfaction at the way that world works - through the mechanisms that men created and refined as emanations of their own system-making drives and modes of collaboration, team patterns that may have originated in prehistoric hunting bands.

Social structures are, in my view, impersonal forms whose smooth operation may require the subordination of individuality, impulse, and emotion (all of which were valorized by the 1960s counterculture generation, including myself). In other words, social structures are abstract and at some level coercive, but for a higher good. Leaders must maintain an ideal balance between the integrity or efficiency of the larger structure and its hospitality or receptivity to its human servants. Many women, from my observation, want a warmer environment and may with all good intentions inject an excess of emotion or personal revelation into institutional functioning, which might sometimes be better served by bland neutrality - an attribute that I used to detest in the WASP social establishment of my youth but that I have come to respect for its workplace utility. Women are still feeling their way toward leadership but are not necessarily getting the best guidance from books like Lean In, an anecdotal 2013 bestseller by Facebook's chief operating officer, Sheryl Sandberg, who is yet another blame-men-first ideologue.

There's considerable research (for example, Brescoll and Uhlmann's (2008) Can an Angry Woman Get Ahead?) that anger, a status emotion, 'works' for male leaders but is dysfunctional for women. Angry men tend to be perceived as angry 'at something' that merits it - but angry women are commonly perceived as simply being in a bad mood. Do you think, based on findings like these, that there's a structural asymmetry in how women can effectively lead?

I find these results fascinating and think they should be taken seriously. If women are to ascend to greater leadership roles, then they must assume responsibility for their own self-presentation in the workplace, which includes subdued clothing choices that avoid easily misread sexual display. On the whole, women tend to speak more rapidly and at a higher register, which can turn shrill under pressure. Western women also smile and use more mobile facial and eye expressions than men. An angry woman may indeed look qualitatively more agitated and even more frightening than an angry man, partly because of the hovering of what psychoanalysis would call the mother imago behind all men's experiences, good or bad, with women. And halfhidden behind that archetype in turn is the worldwide nightmare apparition of the witch.

Frank exploration of these issues is very difficult in the present punitive climate of academic discourse on gender, which polemically ignores biology and asserts that all gender differences are arbitrary, artificial constructions. Human beings, with their advanced intelligence and ingenious adaptability, are not prisoners of biology, but it is irresponsible to refuse to acknowledge the substantial impact on us by nature. Women's now widespread participation in sports, facilitated and expanded by the US Department of Education's Title IX since 1972, has certainly helped girls 
transcend the queen bee syndrome and acquire the basic skills in leadership and teamwork that most boys absorb from childhood in the boisterous dynamics of the playground.

Are there present or past leaders you especially admire and gain inspiration and insight from?

At age 13, I enthusiastically campaigned for John F. Kennedy, who energized my generation after the conformist Eisenhower era. Even today, despite what we now know about his womanizing, drug abuse, nepotism, and failed policies, I am still electrified by JFK's leadership skills when I watch him giving speeches or wittily handling press conferences. As a child, I was infatuated with Napoleon Bonaparte, whose dramatic portraits in military garb appeared in brandy ads. In fact, I masqueraded as Napoleon for Halloween when I was in second grade. Napoleon was certainly one of the classic charismatic leaders of world history: he ambitiously modernized French government and law, laid the groundwork for modern archaeology in Egypt, and induced millions of ecstatic followers to adopt his vision of the future.

However, my admiration for Napoleon waned in adulthood, as I had to face the obscene waste of lives and treasure that he inflicted on Europe and Russia in pursuit of his arrogant imperial ambitions. Now I am more interested in Napoleon's archenemy, Admiral Horatio Lord Nelson, another leader of small stature but of far subtler, more genial temperament. The captains of the great sailing ships had to remain super-alert but cool and removed, channeling their orders through the kinetic first mate. The captain, scanning the horizon, took the long view, a great lesson for all leaders past or present. Indeed, Nelson's death at Trafalgar, where he was targeted from above by a French sniper, was partly the result of his own indifference to the hurly-burly of his immediate environment.

And speaking of famous sea battles, the theme of female leadership is explored in Shakespeare's Antony and Cleopatra, whose climax is the battle of Actium, where Octavius Caesar defeated Mark Antony and Cleopatra and set the stage for the birth of the Roman Empire. Shakespeare (who was born during the reign of Elizabeth I) shows Cleopatra heedlessly overreaching in her role as military commander, which is tragically undermined by her volatility. The military issue is crucial for ambitious American women politicians today. While many Western nations have already had female prime ministers, we have never had a woman president - and that is surely because of the anomaly that the US president is also commander-in-chief of the armed forces. That final glass ceiling may never be broken until women exchange feminist theory for military history and study the demands and challenges of military leadership.

\section{SELECTED BIBLIOGRAPHY OF CAMILLE PAGLIA}

Paglia, Camille. 1990. Sexual Personae: Art and Decadence from Nefertiti to Emily Dickinson. New Haven, CT: Yale University Press.

Paglia, Camille. 1992. Sex, Art, and American Culture: Essays. New York: Vintage.

Paglia, Camille. 1994. Vamps \& Tramps: New Essays by Camille Paglia. New York: Vintage. Paglia, Camille. 2005. Break, Blow, Burn: Camille Paglia Reads Forty-three of the World's Best Poems. New York: Pantheon.

Paglia, Camille. 2012. Glittering Images: A Journey Through Art from Egypt to Star Wars. New York: Vintage. 


\section{REFERENCES}

Brescoll, Victoria L. and Eric Luis Uhlmann. 2008. 'Can an Angry Woman Get Ahead? Status Conferral, Gender, and Expression of Emotion in the Workplace.' Psychological Science, 19(3), 268-275.

Sandberg, Sheryl. 2013. Lean In: Women, Work, and the Will to Lead. New York: Knopf. 